\title{
THE CONTENT OF ANTHOCYANINS AND CHALCONES IN A DECORATIVE SMALL-FRUITED APPLE TREES AND HYBRIDS OF APPLE TREES 'VYDUBETSKA PLAKUCHA'
}

\author{
Levon Volodymyr*, Goncharovska Inna
}

M.M. Gryshko National Botanical Garden of NAS of Ukraine, Kyiv, Ukraine

\section{ВМІСТ АНТОЦІАНІВ ТА ХАЛКОНІВ У ПАГОНАХ КРЕБІВ ТА ГІБРИДІВ ЯБЛУНІ 'ВИДУБИЦЬКА ПЛАКУЧА'}

\author{
Левон Володимир, Гончаровська Інна
}

Received 11. 5. 2017

Revised 22. 5. 2017

Published 29. 11. 2017

\begin{abstract}
The content of anthocyanins and chalcones in a decorative small-fruited Apple trees and hybrids of Apple trees cultivars of Vydubetska plakucha from the collection of the M.M. Gryshko National Botanical Garden of NAS of Ukraine in the conditions of Northern Forest-Steppe of Ukraine was investigated. The study was conducted during periods of active shoot growth and winter dormancy in connection with the adaptive capacity of plants. In the result of the study it was found that a decorative small-fruited Apple trees, that have purple color of leaves, contain a large number of anthocyanins, which cause the bright color. Based on the results of the analysis was found the highest content of anthocyanins in the cultivar Everest, and the lowest - in the cultivar John. Noted that the content of chalcones of the decorative purple hybrids of Apple trees of Vydubetska plakucha variety doesn't have such sharp differences as to the content of anthocyanins. This again confirms the fact that the purple color of the shoots is due to anthocyanins. It is also established that between the content of anthocyanins and chalcones in the shoots of Apple hybrids, cultivars of Vydubetska plakucha found a correlation. The correlation coefficient of 0.84 . This suggests that anthocyanins and chalcones belong to the stress metabolites, the biosynthesis of which is activating during action on vegetable organism to adverse environmental factors, they can serve as biochemical markers of the level of adaptability of the species to stressful conditions. In addition, the description of the Vydubetska plakucha cultivars and hybrids with its participation in the collection of the M.M. Gryshko National Botanical Garden of NAS of Ukraine.
\end{abstract}

Keywords: apple; forms; hybrids; cultivars; ornamental apple trees; anthocyanins; chalcones

\section{Вступ}

У другій половині XX ст. науковими співробітниками Національного ботанічного саду ім. М.М. Гришка НАН України (НБС) на території Видубицького Михайлівського монастиря, який розташований поряд із НБС, було знайдено сорт яблуні, який назвали 'Видубицька плакуча', цікавий, 3 оригінальною плакучою формою крони. Виявилося, що ознака «плакучість» зберігається і при щепленні на штамб. Аби дослідити як передається форма крони при

*Corresponding author: Volodymyr Levon, M.M. Gryshko National Botanical Garden of NAS of Ukraine, Kyiv, Ukraine, $\bowtie$ vflevon@gmail.com 
гібридизації, схрестили її з різними сортами яблуні. Гібриди яблуні з ,Видубицькою плакучою' виявилися різними за морфологічними ознаками. В той же час біохімічні дослідження у зв'язку з адаптивними властивостями гібридів в умовах Лісостепу України не проводилися.

Зважаючи на те, що однією із особливостей адаптації $€$ наявність антоціанів, поставили завдання визначити їх у зв'язку із зимо- і посухостійкістю.

Історичні дані свідчать про те, що „Видубицька плакуча' - це, очевидно старовинний сорт яблуні виведений А. Дюрингом наприкінці XIX ст. у м. Ельбінгу (Німеччина). Сорт був проданий пепін'єристу Францу Ратке, який дав йому ім'я Еліза Ратке (Симиренко, 1972).

За нашими даними, сорт яблуні Видубицька плакуча - це синонім стародавнього сорту Еліза Ратке, інтродукованого до всесвітньовідомого розсадника Л.П. Симиренка наприкінці XIX ст. Ми встановили, що за морфологічними, помологічними та господарськими ознаками сорт яблуні Видубицька плакуча $\epsilon$ аналогом сорту яблуні Еліза Ратке.

Від Л.П. Симиренка вона розповсюдилася в Україні у різні розсадники i, зокрема, монастирі, які завжди були провідниками нових ідей і сортів. Отже, очевидно, „Еліза Ратке' на якийся час загубилась, але збереглася у монастирі.

Дослідження вмісту біологічно-активних речовин у кребах та гібридах яблуні 'Видубицька плакуча’ в умовах Лісостепу України проведено вперше.

Антоціани - найважливіші пігменти рослин. Вони забарвлюють пелюстки квіток, плоди, іноді листки у блакитний, синій, рожевий, червоний, фіолетовий кольори з різними відтінками і переходами. Всі антоціани - глікозиди. Агліконами антоціанів $\epsilon$ антоціанідини. Антоціани розчиняються у воді і містяться у клітинному соку (Lila, 2004).

Антоціани - природні барвні речовини рослин з групи флавоноїдів. Утворенню антоціанів сприяють низька температура, інтенсивне освітлення, але повністю їх біологічні функції поки не з'ясовані. Антоціани надають колір пелюсткам квіток, сприяючи тим самим залученню комахзапилювачів (Танчев, 1980; Карабанов, 1981; Чуб, 2008).

Найбільшу кількість антоціанів накопичують рослини в місцевостях з суворими кліматичними умовами. Вони поглинають світло в ультрафіолетовій та зеленій областях спектру. Поглинена енергія частково перетворюється на тепло, підвищуючи на $1-4{ }^{\circ} \mathrm{C}$ температуру листя, маточок, тичинок. Це створює більш сприятливі умови, як для фотосинтезу, так і для запліднення і проростання пилку в умовах знижених температур (Чуб, 2008). У високогірних рослин антоціани, поглинаючи надлишок сонячної радіації, захищають хлорофіл і спадковий апарат клітини від пошкоджень. Рослини, що містять велику кількість антоціанів, мають підвищену стійкість до забруднення повітря кислими газами промислових підприємств (Масленников, 2003).

Поступаючи в організм людини з фруктами і овочами, антоціани підтримують нормальний стан кров'яного тиску і судин, запобігаючи внутрішнім крововиливам. Утворюючи комплекси з радіоактивними елементами, антоціани сприяють швидкому виведенню їх з організму. Крім того, ці пігменти здатні поліпшувати зір (Танчев, 1980).

Одним з найбільш поширених пігментів - антоціан ціанідин, цей пігмент в першу чергу відповідає за червоне забарвлення яблучної шкірки (Lancaster, 1992; Tsao, 2003).

Халкони, або антохлори - це флавоноїди з розкритим гетероциклом. Вони надають пелюсткам квіток жовтого кольору. Їх поширення обмежене дев'ятьма родинами. Містятьться вони у вигляді глікозидів. Халконами, наприклад, $\epsilon$ ізосаліпурпозид із жовтих квіток гвоздики, флоридзин із кори і листків яблуні (Удовенко, 1988).

Метою нашої роботи було визначення вмісту антоціанів та халконів у пагонах кребів та гібридів яблуні 'Видубицька плакуча'у періоди активного росту пагонів та зимового спокою у зв'язку з їх адаптаційною здатністю. 


\section{Матеріали та методи}

Об'єкти досліджень - представники роду Malus Mill. - сорт яблуні Видубицька плакуча (В.п.) і гібриди з її участю та дрібноплідні декоративні яблуні (креби) із колекції НБС.

Наводимо опис сорту Видубицька плакуча та гібридів з її участю колекції НБС НАН України.

Сорт яблуні Видубицька плакуча - дерево низькоросле, майже сланке (висота штамба 40 - 50 см), дуже декоративне, листя зелене, квітки від рожевого до білого кольорів, плоди масою - 113,9 - 183,0 г, кількість насінин в 1 плоді - 6 шт. Плоди жовті із червоним рум'янцем, крона плакуча.

Гібрид В.п. $\times$ Malus baccata (рік посадки - 1979) - висота штамбу - 120 см, діаметр - 24,4 см. Листкова пластинка (середні значення) - довжина - 64,86 см, ширина - 39,78 см. Листя зелене, плоди масою - 6,3 - 8,5 г. Квітки від яскраво-малинового до рожевого кольорів. Плоди жовті із червоним рум'янцем, крона плакуча.

Гібрид Видубицька плакуча (В.п.) × Ренет Кокса Оранжевий (рік посадки - 1985) - висота штамбу - 140 см, діаметр - 12,8 см. Листкова пластинка (середні значення) - довжина - 79,33 см, ширина - 47,98 см. Листя зелене, квітки від рожевого до білого кольорів, плоди масою - 183,0 113,9 г, жовто-оранжеві із червоним рум'янцем, крона плакуча.

Гібрид В.п. × Мекінтош (рік посадки - 1983) - висота штамбу - 205 см, діаметр - 24,5 см. Листкова пластинка (середні значення) - довжина - 109,69 см, ширина - 47,87 см. Листя зелене, квітки від рожевого до білого кольорів, плоди масою - 30,2 - 99,4 г, жовті із червоним рум'янцем, крона плакуча.

Гібрид В.п. × Пепін Шафранний (рік посадки - 1982) - висота штамбу - 125 см, діаметр - 9,8 см. Листкова пластинка (середні значення) - довжина - 82,24 см, ширина - 42,07 см. Листя зелене, квітки від рожевого до білого кольорів, плоди масою - 42,1 - 55,8 г, жовті, кількість насінин в 1 плоді - 9 шт. Крона плакуча.

Гібрид В.п. $\times$ Уральське наливне (рік посадки - 1982) - висота штамбу - 118 см, діаметр 19,1 см. Листкова пластинка (середні значення) - довжина - 87,32 см, ширина - 55,97 см. Листя зелене, плоди масою - 183,0 - 113,9 г, червоні. Квітки від яскраво-малинового до рожевого кольорів. Крона плакуча.

Гібрид В.п. × Апорт - висота штамбу (рік посадки - 1985) - 193 см, діаметр - 16,5 см. Листкова пластинка (середні значення) - довжина - 90,77 см, ширина - 65,35 см. Листя зелене, квітки від рожевого до білого кольорів, плоди масою - 183,0 - 113,9 г, жовто-рожеві із червоним рум'янцем, крона плакуча.

Гібрид В.п. × Айдаред (рік посадки 1982) - висота штамбу - 225, діаметр - 25,3 см. Листкова пластинка (середні значення) - довжина - 79,66 см, ширина - 52,99 см. Листя зелене, квітки від рожевого до білого кольорів, плоди масою - 183,0 - 113,9 г, червоного кольору, крона плакуча.

Гібрид В.п. × Оранжеве (рік посадки 1983) - висота штамбу - 90 см, діаметр - 15,2 см. Листкова пластинка (середні значення) - довжина - 70,78 см, ширина - 42,91 см. Листя зелене, квітки від рожевого до білого кольорів, плоди масою - 183,0 - 113,9 г, жовто-оранжеві із червоним рум'янцем, крона плакуча.

Кількість антоціанів визначали фотоелектроколориметричним методом за довжини хвилі 530 нм, використовуючи спиртову витяжку з гомогенату рослинної сировини, підкислену 3,5 \% соляною кислотою. Якщо аналізований зразок, крім антоціанів, містить інші пігменти, наприклад, флавоноли жовтого забарвлення, то оптичну густину досліджуваного розчину вимірюють по відношенню до його частини, але після знебарвлення пероксидом водню. Якщо інших пігментів немає, визначення оптичної густини антоціанів роблять по відношенню до води (Кривенцов, 1982). 
Визначення халконів проводили за методикою Г.В. Удовенко (1988), модифікованою В.Ф. Левоном одночасно із визначенням антоціанів. У випадку великої оптичної щільності розчин розводили у 5 - 10 раз 0,1 \% розчином соляної кислоти. Вимірювання проводили за довжини хвилі 364 нм.

Зразки було відібрано у період активного росту пагонів та у період зимового спокою.

\section{Результати та їх обговорення}

У 2016 році визначали вміст антоціанів та флавонолів у надземних органах декоративних форм представників роду Malus: вид - яблуня Недзвецького (Malus niedzwetzkyana), гібриди В. п. $\times$ Malus baccata, В. п. × Старкрімсон, креби - Джон, Роялті Ред, Роялті, Ера, Еверест, Ола, Райка Рожева та Професор Шпенглер.

Виходячи із результатів аналізу, встановили, що найбільший вміст антоціанів у сорту Еверест, а найменший - у сорту Джон (рис. 1).

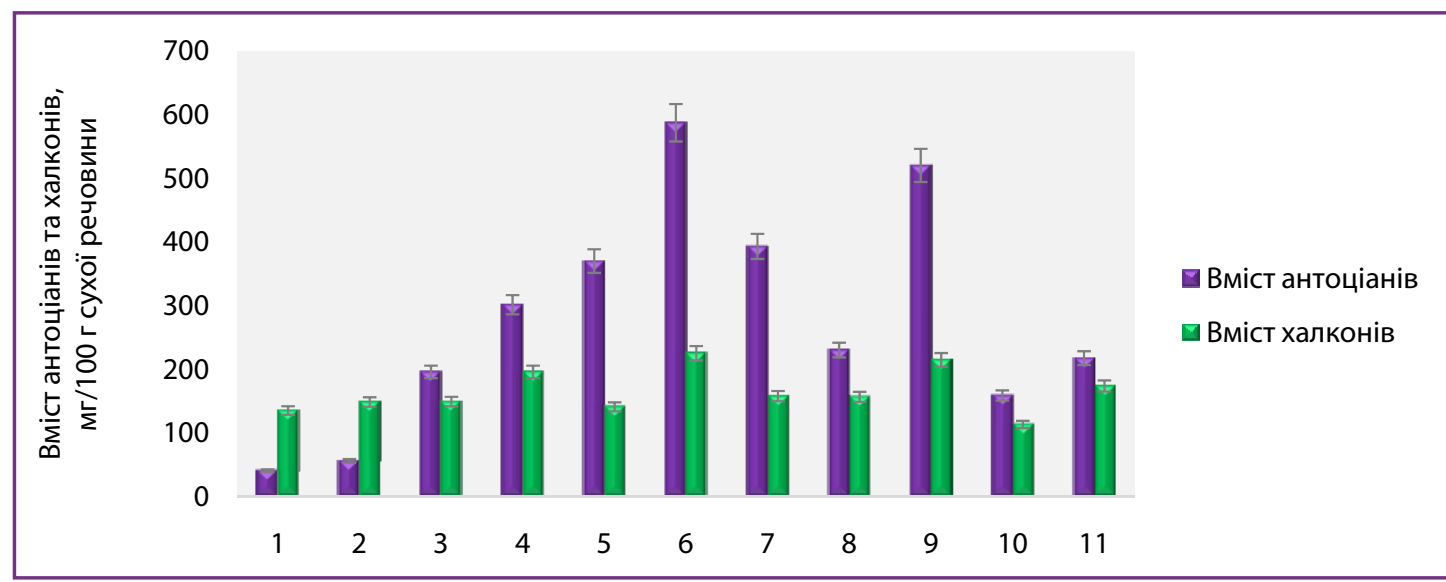

Рисунок 1 Порівняльний вміст антоціанів та флавонолів у пагонах декоративних форм і сортів представників роду Malus Mill.

1 - Джон; 2 - В. п. × Malus baccata; 3 - Роялті Ред; 4 - Роялті; 5 - Ера; 6 - Еверест; 7 - Недзвецького; 8 - Ола; 9 - Рожева; 10 - В. п. × Старкрімсон; 11 - Професор Шпренгер

Figure 1 Comparative content of anthocyanins and flavonols in shoulder straps of decorative forms and cultivars of representatives of the genus Malus Mill.

1 - John; 2 - V. p. $\times$ Malus baccata; 3 - Royal Red; 4 - Royalti; 5 - Era; 6 - Everest; 7 - Niedzwiecki; 8 - Ola; 9 - Rozeva; 10 - V. p. $\times$ Starkrimson; 11 - Professor Shprenger

У 2017 році визначали вміст антоціанів та халконів у пагонах декоративних форм представників роду Malus, а саме: Видубицька плакуча × Ренет Симиренко, Видубицька плакуча, В. п. $\times$ Старкрімсон, В. п. × Malus baccata, В. п. $\times$ Ренет Кокса Оранжевий, В. п. $\times$ Уральське наливне, В. п. $\times$ Слава переможцям, В. п. $\times$ Оранжеве, В. п. $\times$ Антор у період зимового спокою. Встановлено, що найбільший вміст вищезгаданих біологічно-активних сполук має сорт Видубицька плакуча. Вміст антоціанів сягає позначки 218, а флавонолів - 188 мг/100 г сухої речовини. Також досить високий вміст антоціанів і халконів має гібрид В. п. $\times$ Ренет Кокса Оранжевий (208 та 144 мг/100 г сухої речовини відповідно). 


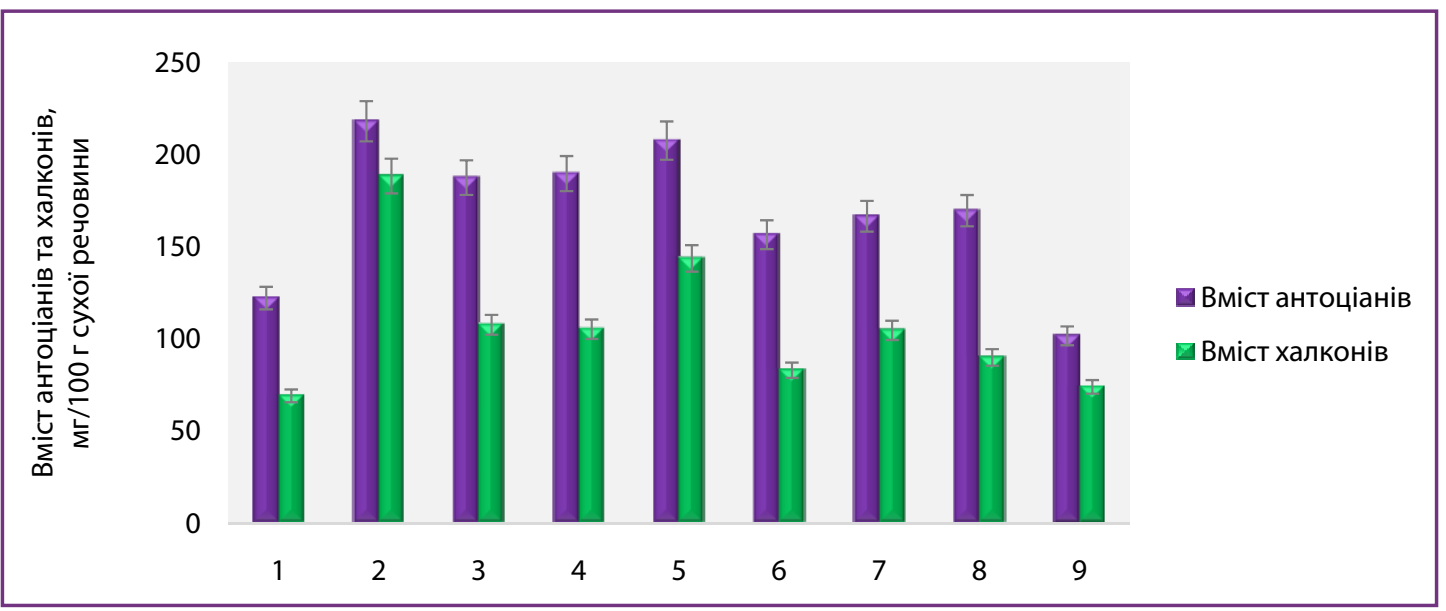

Рисунок 2 Вміст антоціанів та халконів у пагонах сортів та гібридів декоративних форм представників роду Malus Mill. у період зимового спокою

1 - Видубицька плакуча × Ренет Симиренка, 2 - Видубицька плакуча, 3 - В. п. × Старкрімсон, 4 - В. п. × Malus baccata, 5 - В. п. × Ренет Кокса Оранжевий, 6 - В. п. $\times$ Уральське наливне, 7 - В. п. $\times$ Слава переможцям, 8 - В. п. $\times$ Оранжеве, 9 - В. п. $\times$ Антор

Figure 2 The content of anthocyanins and chalcons in shoots of cultivars and hybrids of decorative forms of representatives of the genus Malus Mill. during the winter calm

1 -Vydubetska plakucha $\times$ Renet Symyrenka, 2 -Vydubetska plakucha, $3-$ V. p. $\times$ Starkrimson, $4-$ V. p. $\times$ Malus baccata, 5 - V. p. $\times$ Renet Koksa Oranzevyi, 6 - V. p. $\times$ Uralske nalyvne, $7-$ V. p. $\times$ Slava peremozhcyam, $8-$ V. p. $\times$ Oranzeve, $9-$ V. p. $\times$ Antor

\section{Висновки}

В результаті досліджень за 2016 - 2017 рр. було встановлено, що за вмістом халконів декоративні пурпурові та гібриди яблуні сорту Видубицька плакуча не мають таких різких відмінностей, як за вмістом антоціанів. Це ще раз підтверджує той факт, що пурпурове забарвлення пагонів обумовлене саме антоціанами. Слід відзначити, що між вмістом антоціанів і халконів у пагонах декоративних форм представників роду Malus знайдено корелятивний зв'язок. Коефіцієнт кореляції досить високий і дорівнює 0,84 (максимально можливий = 1). Це свідчить про те, що антоціани та халкони належать до стресових метаболітів, біосинтез яких активізується під час дії на рослинний організм несприятливих факторів навколишнього середовища, отже вони можуть слугувати біохімічними маркерами рівня адаптованості видів до стресових умов.

\section{Література}

Lancaster, J. 1992. Regulation of skin color in apples. Crit. Rev. Plant. Sci., vol. 10, p. 487-502. http://dx.doi. org/10.1080/07352689209382324

Lila, M.A. 2004. Anthocyanins and Human Health: An In vitro Investigative Approach. J. Biomed Biotechnol, vol. 5, p. 306-313. DOI: 10.1155/S111072430440401X

Tsao, R. 2003. Polyphenolic profiles in eight apple cultivars using high-performance liquid chromatography (HPLC). J. Agric. Food Chem., vol. 51, p. 6347- 6353. DOI: 10.1021/jf0346298

Карабанов, И.А. 1981. Флавоноиды в мире растений. Минск. Ураджай. 80 с.

Кривенцов, В.И. 1982. Методические рекомендации по анализу плодов на биохимический состав. Ялта. 21 с.

Масленников, П.В. 2003. Экологические аспекты накопления антоціановых пигментов в растениях : автореф. дис. на соискание науч. степени канд. биологических наук. Калининград. 25 с. 
Симиренко, Л.П. 1972. Помология. Яблоня. Киев: Урожай. 436 с.

Танчев, С.С. 1980. Анточіаны в плодах и овощах. М.: Пищевая промышленность. 304 с.

Удовенко, Г.В. 1988. Диагностика устойчивости растений к стрессовым воздействиям (Методическое руководство). Ленинград: ВИР. 230 с.

Чуб, В.И. 2008. Для чего нужны антоціаны. Цветоводство, № 6, с. 22-25. 